\title{
ANALYSIS OF LABOR PRODUCTIVITY OF REINFORCED CONCRETE ON INDONESIAN NATIONAL STANDARD 2002: A CASE STUDY AT THE CONSTRUCTION OF OFFICE BUILDINGS IN BONTANG KUALA DISTRICT OF BONTANG CITY
}

\author{
Lukman, Researcher \\ Sutanto Hidayat, Tiong Iskandar, Lecturers \\ National Institute of Technology, Malang, East Java, Indonesia \\ ${ }^{*}$ E-mail: tajangjaya01@gmail.com \\ ORCID: 0000-0002-2254-2033
}

\begin{abstract}
The objectives of this research are to: 1) analyze the Labor Productivity Of Reinforced Concrete, 2) analyze difference in real labor productivity of reinforced concrete of the results of the study compared to the labor productivity of reinforced concrete of the Indonesian National Standard (SNI) 2002, 3) analyze what factors influence the labor productivity of reinforced concrete of office buildings of Bontang Kuala District in Bontang City, 4) Analyze the most dominant factors affecting the labor productivity of reinforced concrete in the construction of the office buildings of Bontang Kuala District in Bontang City. This study uses a survey method by capturing opinions, experiences and attitudes of respondents to obtain primary data through a questionnaire as a data collection tool and secondary from the related institutions. Based on the results of this study, namely from the $F$ test, it was found that Motivation factors (X1), Skills (X2), Discipline (X3), Education (X4), Experience (X5), Wages / Salaries (X6) and Age (X7) had an effect simultaneously on the labor productivity of reinforced concrete, with the value of Fcount $=10.470>$ Ftable $=2.210$. In conclusion, the most dominant variable on reinforced concrete labor productivity is experience (X5) with an $\beta$ coefficient of 1.753 . Experience is the main factor in producing a product.
\end{abstract}

\section{KEY WORDS}

Productivity, labor, reinforced concrete, service.

Human resources are very important factors to facilitate a job, especially construction projects. Without the human resources involved in it, the construction projects cannot be held. Because of the importance of these factors, the planning of the number of workers and the arrangement of the parts in it, it should be conducted with a varied of careful considerations (Noe et. al., 2006). In implementing a construction project, the role of labor is an important factor. Because the factor of labor has a direct effect on the cost, time of project implementation, and the quality which expected of that project (Soeharto, 2001). Whereas according to Kaming, et al. (1997), stated that when the contractor deals the tender in carrying out the project work which located in the area, the contractors will always be facing several alternative of labor supply. namely: 1) taking construction workers from other group with good quality and experience, 2) giving the labor issues to sub-contractors (bulk), 3) taking labor from the other group but only for workers with expertise not available in work location.

From these three alternatives, they prove that the level of labor productivity is an important consideration in planning and implementing project activities. According to Soeharto (2001), stated that the portion of labor costs can reach $35-40 \%$ of the total cost of the project, so it needs an in-depth study of the workforce itself. In addition, planning a project activity needs to be done carefully so that the costs, timing of implementation and the quality of a job can be accounted for.

In studying the problem of productivity, it is inseparable from the aspect of productivity itself as well as several problems related to productivity such as the work of the workforce itself, motivation to work, expertise / skills, level of wage / salary, level of education, age and an discipline (Omachonu, 2012). Low labor productivity can lead to delay in a work project, 
which in turn can also cause overruns the cost (Smith, 2002). Therefore, assessment of the analysis of the causes of weakening productivity must be done carefully, however, every source of problems and causes of failure is very important to understand and pay attention to, especially an effort to increase productivity (McGrath, 2004).

Bontang Kuala City is one of the cities in East Kalimantan province, which is actively engaged in development in various development sectors. In the infrastructure development sector, namely the provision of development facilities and infrastructure, especially in the field of building construction, the Mayor urged that development be carried out more effectively, efficiently, economically and the deadline for completion of construction should not exceed the fiscal year that determined by the government of Bontang city. In calculating the budget plan (RAB) in the implementation of the construction of office buildings of Bontang Kuala District in Bontang City has been using the Indonesian National Standard (SNI 2002).

Budget planning of building construction in Indonesia has referred to the use of SNI 2002 with the hope that in calculating the budget plan, labor is more productive, and development costs can be saved from $8-10 \%$ and labor costs range from $23-28 \%$ (Tjaturono, 2002). Factors that influence labor productivity, including factor of job location, skill factors, working time and local life index (Dipohusodo, 1995) and the most important is the labor factor itself (Kaming, 2000). Other factors that affect labor productivity include: education, experience, motivation, wages, age of productivity, weather, topography, material location. The study regarding Labor productivity have been carried out by many previous researchers, all of which were carried out on the island of Java, where the skills / expertise, education and work motivation of the workers on the island of Java were thought to be different from the workers on the island of Kalimantan, especially the city of Bontang kuala, in addition to natural / topographic conditions, local customs also influence the level of labor productivity. Therefore, research on labor productivity, especially reinforced concrete labor in Bontang kuala city needs to be conducted.

The labor productivity of reinforced concrete of the construction of Office Buildings of Bontang Kuala District in Bontang City is quite varied, this can be viewed from the timely settlement and there are jobs that cannot be completed on time. This is thought to be caused by several factors such as motivation to work, expertise / skills, Discipline, level of education, Experience, Wages / Salaries and Age.

Formulation of the problem:

- How much the labor productivity of reinforced concrete in the construction of Office Buildings of Bontang Kuala District in Bontang City?

- How big is the difference in real labor productivity of reinforced concrete of the research results compared to the labor productivity of reinforced concrete in the Indonesian National Standard (SNI) 2002?

- What factors influence the labor productivity of reinforced concrete in the construction of Office Buildings of Bontang Kuala District in Bontang City?

- Which of the most dominant factors that influences the labor productivity of reinforced concrete in the construction of Office Buildings of Bontang Kuala District in Bontang City?

Research Purposes:

- Analyzing the labor productivity of reinforced concrete labor in the construction of Office Buildings of Bontang Kuala District in Bontang City;

- Analyzing difference in real labor productivity of reinforced concrete of the results of the study compared to the labor productivity of reinforced concrete of the Indonesian National Standard (SNI) 2002;

- Analyzing what factors influence the labor productivity of reinforced concrete of office buildings of Bontang Kuala District in Bontang City;

- Analyze the most dominant factors affecting the labor productivity of reinforced concrete in the construction of the office buildings of Bontang Kuala District in Bontang City. 


\section{METHODS OF RESEARCH}

Type and Location of Research. This study is included in descriptive research, namely to determine the magnitude of labor productivity, factors that affect labor productivity and the most dominant factors influence and to know the magnitude of the difference in real labor productivity of reinforced concrete of the research results compared to the labor productivity of reinforced concrete for Standards National Indonesia 2002 in Bontang City, East Kalimantan province. This study uses a survey method by capturing opinions, experiences and attitudes of respondents to obtain primary data through a questionnaire as a data collection tool and secondary from the relevant institutions. Based on the factors that affect the labor productivity of reinforced concrete in the construction of Office Buildings of Bontang Kuala District in Bontang City, then the factors that are followed by determining the variables to be used as questions, they will be determined in the form of a questionnaire. The location of this study was carried out on the construction of the Bontang Kuala Village Office building in Bontang City, East Kalimantan Province in 2016.

Population and sample. In this study, the population is the labor productivity of reinforced concrete who know the conditions and work or are directly involved in the construction Office Buildings of Bontang Kuala District in Bontang City, East Kalimantan province in the 2016 fiscal year, which is about 55 workers, taken from people people who work in the construction of Office Buildings of Bontang Kuala District in Bontang City. In this study, the sample was taken randomly by using Disproportionate Stratified Sampling (Sugiono, 2006).

From the results of this calculation, the total number of samples that will be taken, it is 48 respondents of reinforced concrete labor, taken from people who work in the construction of Office Buildings of Bontang Kuala District in Bontang City. Work for column structure is 12 people, work for beam structure is 18 people, work for floor structure is 18 people.

Data collection. Data collection is done by using observations and questionnaires. Observations were made to determine the magnitude of labor productivity of reinforced concrete, while the questionnaire in obtaining the factors that influence the labor productivity of reinforced concrete in the work construction of Office Buildings of Bontang Kuala District in Bontang City which using a Likert scale modified with range 1 to 3 . The author uses a range of 1 to 3 to avoid the middle value (doubtful) which is difficult to interpret between agreeing and disagreeing, so that the firmness of the respondents in answering questions from the questionnaire is obtained. The items in the variables of the study are designed (designed) with positive questions, so that the number one is a code of respondent's response that is very negative for one of the questions, while number three is to give a very positive response (Azwar, 1999).

Data Collection Techniques. Conducting the observations and direct measurements in the field to calculate labor results in reinforced concrete. The working time start at 08.00 to 16.00 with lunch breaks and others for approximately 1 (one) hour from 12.00 to 13.00 , so effective work schedule is 7 hours. Data collection on the location of the project, such as the amount of labor and material, weather, employment conditions and availability of tools used. Recording and calculation the result of labor of reinforced concrete in the construction of Office Buildings of Bontang Kuala District in Bontang City 2016. Measurements and enumerations are carried out in the afternoon after completion of work. Record the time required for labor reinforced concrete, methods and equipment used. Fill out questionnaires for factors that affect the labor productivity.

Processing and Analysis of Data. Data obtained from survey results (questionnaires), it will be processed to obtain an information into table form. The processed data results are used to answer the questions related to the magnitude of the labor productivity of reinforced concrete, the factors that affect the labor productivity of reinforced concrete and the most dominant factors affect the labor productivity of reinforced concrete in the construction of Office Buildings of Bontang Kuala District in Bontang City.

Data processing should pay attention to the type of data collected by being oriented to the objectives to be achieved. The accuracy of analytical techniques greatly influences the 
accuracy of the results of the study. The power analysis technique used is descriptive statistics, factor analysis, multiple linear regression analysis and one sample t test. The results of the questionnaire data from each variable are then scaled back, so that each of the variables containing several indicators will produce only one score value which is then analyzed by using descriptive analysis, factor analysis, multiple linear regression analysis and one sample t test. Data processing is done with an assisted of Statistical Package and Service Solution (SPSS) for Windows.

Equation of Research Results. The equalization of the results of research by using Indonesian National Standard (SNI) 2002 was carried out on 2 (two) parts, namely the equalization of working time (working time), and the equalization of the composition of workmanship and workers. This equalization is caused by the working time (working time) between the results of research with Indonesian National Standard (SNI) 2002 differently, as well as the composition of work of workmanship and workers. As a reference in equalizing the composition of workmanship and workers, it is necessary to adjust the type of work and the composition of the worker and the worker under study. This research is only an labor reinforced concrete with a composition of 1 artisan, 2 workers, while Indonesian National Standard (SNI) 2002 has 1 artisan composition: 1 1/2 workers in accordance for labor of reinforced concrete with factors of 1.47 for composition of 1 worker : 2 workers, while SNI 2002 has a factor of 1.20. As for equalizing of working time, then working time of Indonesian National Standard SNI 2002 are divided into Indonesian National Standard from the research results, this is because the working time of the research results are 7 working hours / day, while Indonesian National Standard (SNI) 2002 is only 5 working hours / day.

Table 1 - Productivity Adjustment Factors for Artisan and Workers Composition

\begin{tabular}{|c|c|c|c|c|c|c|c|c|}
\hline \multirow{2}{*}{ No } & \multirow{2}{*}{ Type of activity } & \multicolumn{7}{|c|}{ Composition between artisan and workers } \\
\cline { 3 - 9 } & & $1: 1 / 2$ & $1: 1$ & $1: 11 / 4$ & $1: 11 / 2$ & $1: 2$ & $1: 21 / 2$ & $1: 3$ \\
\hline 1 & Pas. Bowplank & 0,62 & 1,00 & - & 1,10 & 1,24 & - & - \\
\hline 2 & Pas. Batu Kali & - & 0,68 & - & 0,84 & 1,00 & 1,03 & 1,06 \\
\hline 3 & Cor Beton & - & 1,00 & - & 1,20 & 1,47 & - & - \\
\hline 4 & Pas. Batu Merah & - & 0,67 & - & 0,82 & 1,00 & 1,06 & - \\
\hline 5 & Pas. Genteng & - & 0,60 & - & 0,75 & 1,00 & - & - \\
\hline 6 & Plesteran & - & 0,80 & 0,90 & 1,00 & 1,02 & - & - \\
\hline 7 & Pas. Tegel Lantai & 0,75 & 1,00 & - & 1,07 & 1,09 & - & - \\
\hline
\end{tabular}

\section{RESULTS OF STUDY}

Partial Test of Regression Models. Partial testing of regression models is used to determine whether each of the independent variables forming of regression model individually has a significant influence on the labor productivity of reinforced concrete or not. To test this relationship, the $t$ test is used, which is by comparing the tcount to $t$ table. The independent variable forming of regression model is stated to have a significant effect if $t$ count $>t$ table or $p$-value $<\alpha=0.05$. Partial testing of the regression model can be viewed as follows:

Hypothesis testing of regression coefficients of Motivation to work variables (X1) can be written in Table 2.

Motivation to work variable has a regression coefficient of 0.187 . By using an assisted of SPSS software, the t test statistic obtained is 0.202 with a p-value of 0.841 . The statistical value of the $t$ test is greater than $t$ table $(0.202<1.683)$ and also $p$-value is greater than $\alpha=$ 0.05. This test indicates that $\mathrm{HO}$ is accepted. So it can be concluded that the level of motivation to work does not significantly influence the labor productivity of reinforced concrete.

Hypothesis testing of regression coefficients of expertise / skills variables (X1) can be written in Table 3.

Expertise / skill variable has a regression coefficient of 0.582 . By using an assisted of SPSS software, the $t$ test statistic obtained is 1,180 with a $p$-value of 0.841 . The statistical value of the $t$ test is greater than $t$ table $(0.202<1.683)$ and also $p$-value is greater than $\alpha=$ 
0.05. This test indicates that $\mathrm{HO}$ is rejected. So it can be concluded that the level of skills does not significantly influence the labor productivity of reinforced concrete.

Hypothesis testing of regression coefficients of discipline variables (X1) can be written in Table 4.

Table 2 - Hypothesis Test for motivation to work Variable Regression Coefficient

\begin{tabular}{|l|l|l|}
\hline \multicolumn{1}{|c|}{ Hypothesis } & \multicolumn{1}{|c|}{ Score } & \multicolumn{1}{c|}{ Conclusion } \\
\hline $\mathrm{H} 0: \beta \mathrm{i}=0$ (motivation to work variable does not significantly influence the & $\mathrm{t}=0,202$ & \\
labor productivity of reinforced concrete) & $p$-value $=0,841$ \\
$\begin{array}{l}\mathrm{Ha}: \beta \mathrm{i} \neq 0 \text { (motivation to work variable has a significant effect on labor } \\
\text { productivity of reinforced concrete) } \alpha=0.05\end{array}$ & $\begin{array}{l}\text { Accept } \mathrm{H}_{0} \\
\text { Tabel }=1,683\end{array}$ & \\
\hline
\end{tabular}

Table 3 - Hypothesis Test for expertise / skills Variable Regression Coefficient

\begin{tabular}{|c|c|c|}
\hline Hypothesis & Score & Conclusion \\
\hline $\begin{array}{l}\mathrm{H} 0: \beta \mathrm{i}=0 \text { (expertise / skills variable does not significantly influence the } \\
\text { labor productivity of reinforced concrete) } \\
\mathrm{Ha:} \beta \mathrm{i} \neq 0 \text { (expertise / skills variable has a significant effect on labor } \\
\text { productivity of reinforced concrete) } \alpha=0.05\end{array}$ & $\begin{array}{l}\mathrm{t}=1,180 \\
p \text {-value }=0,245 \\
\mathrm{t}_{\text {Tabel }}=1,683\end{array}$ & Accept $\mathrm{H}_{0}$ \\
\hline
\end{tabular}

Table 4 - Hypothesis Test for discipline of Variable Regression Coefficient

\begin{tabular}{|l|l|l|}
\hline \multicolumn{1}{|c|}{ Hypothesis } & \multicolumn{1}{|c|}{ Score } & Conclusion \\
\hline $\begin{array}{l}\text { Ha: } \beta 3 \neq 0 \text { (disciplinary variables have a significant effect on the labor } \\
\text { productivity of reinforced concrete), } \alpha=0.05\end{array}$ & $\begin{array}{l}\mathrm{t}=-0,341 \\
p \text {-value }=0,735 \\
\mathrm{t}_{\text {Tabel }}=1,683\end{array}$ & Accepted $\mathrm{H}_{0}$ \\
\hline
\end{tabular}

Discipline variable has a regression coefficient of $-0,328$. By using an assisted of SPSS software, t-test statistics were obtained at -0.3341 with a p-score of 0.735 . The statistical score of the $t$ test is greater than $t$ table $(-0.334<1.683)$ and also $p$-score is greater than $\alpha=$ 0.05. This test indicated that $\mathrm{Ho}$ is accepted. So that it can be concluded that the level of discipline of workers does not significantly influence the labor productivity of reinforced concrete.

Hypothesis testing of the regression variables for education variables (X4) can be written in table 5 as follows:

Table 5 - Hypothesis Test fpr Educational of Variable Regression Coefficients

\begin{tabular}{|l|c|c|}
\hline \multicolumn{1}{|c|}{ Hypothesis } & Score & Conclusion \\
\hline H0: $\beta 4=0$ (education variable does not significantly influence the labor & $t=-0,767$ & \\
productivity of reinforced concrete) & $p$-value $=0,448$ \\
$\begin{array}{l}\text { Ha: } \beta 4 \neq 0 \text { (education variable has a significant effect on the labor } \\
\text { productivity of reinforced concrete), } \alpha=0.05\end{array}$ & Accepted Ho \\
\hline
\end{tabular}

Educational variable has a regression coefficient of -0.256 . By using the help of SPSS software, $t$-test statistics were obtained at -0.767 with a p-value of 0.448 . The t-test statistic value is greater than $t$ table $(0.209<1.683)$ and also $p$-value is greater than $\alpha=0.05$. This test indicates that $\mathrm{Ho}$ is accepted. So it can be concluded that the level of education does not significantly influence the productivity of reinforced concrete labor.

Testing the hypothesis of the coefficient of regression of experience variable (X5) can be written in Table 6 as follows:

Table 6 - Hypothesis Test for experience of Variable Regression Coefficients

\begin{tabular}{|l|c|}
\hline \multicolumn{1}{|c|}{ Hypothesis } & Score \\
\hline H0: $\beta 5=0$ (experience variable does not significantly influence the labor & \\
productivity of reinforced concrete) & $t=4,255$ \\
Ha: $\beta 4 \neq 0$ (experience variable has a significant effect on the labor & $p-v a l u e=0,000$ \\
productivity of reinforced concrete), & $t_{\text {Tabel }}=1,683$ \\
$\alpha=0.05$ & \\
\hline
\end{tabular}


Experience variable has a regression coefficient of 1.753. By using the help of SPSS software, the tcount test statistic obtained is 4.255 with a p-value of 0.000 . The t-test statistic value is greater than $t$ table $(4.255>1.683)$ and also $p$-value is greater than $\alpha=0.05$. This test shows that $\mathrm{Ho}$ is rejected. So that it can be concluded that the level of discipline of workers has a significant effect on the productivity of reinforced concrete labor.

Hypothesis testing of the regression variables for wage / salary (X4) can be written in table 7 as follows:

Table 7 - Hypothesis Test for wage / salary of Variable Regression Coefficients

\begin{tabular}{|l|c|c|}
\hline \multicolumn{1}{|c|}{ Hypothesis } & Score & Conclusion \\
\hline $\mathrm{H} 0: \beta 6=0$ (wage / salary variable does not significantly influence the productivity & $\mathrm{t}=-0,978$ & \\
of reinforced concrete labor) & $p$-value $=$ & Accepted \\
$\mathrm{Ha:} \beta 6 \neq 0$ (variable wage / salary has a significant effect on the productivity of & 0,334 & Ho \\
reinforced concrete labor), & $\mathrm{t}_{\text {Tabel }}=1,683$ & \\
$\alpha=0.05$ & \\
\hline
\end{tabular}

The wage / salary variable has a regression coefficient of $-0,368$. By using the help of SPSS software, t-test statistics were obtained at -0.978 with a $p$-value of 0.334 . The $t$-test statistic value is greater than t table $(-0.978<1.683)$ and also $p$-value is greater than $\alpha=$ 0.05 . This test shows that $\mathrm{Ho}$ is accepted. So it can be concluded that the wage / salary level does not significantly influence the labor productivity of reinforced concrete.

Testing the hypothesis regression coefficient wage / salary variable (X6) can be written in Table 8 as follows:

Table 7 - Hypothesis Test for age of Variable Regression Coefficients

\begin{tabular}{|l|c|c|}
\hline \multicolumn{1}{|c|}{ Hypothesis } & Score & Conclusion \\
\hline $\mathrm{H} 0: \beta 7=0$ (age variable does not significantly influence the productivity of & $\mathrm{t}=3,612$ & \\
reinforced concrete labor) & $p$-value $=$ & Accepted \\
Ha: $\beta 7 \neq 0$ (age variable has a significant effect on the productivity of reinforced & 0,001 & Ho \\
concrete labor), & $\mathrm{t}_{\text {Tabel }}=1,683$ & \\
$\alpha=0.05$ & & \\
\hline
\end{tabular}

The age variable has a regression coefficient of 1.484. By using the help of SPSS software, the tcount test statistic obtained is 3,612 with a p-value of 0,001 . The t-test statistic value is greater than $t$ table $(3.612>1.683)$ and also $p$-value is greater than $\alpha=0.05$. This test shows that Ho is rejected. So that it can be concluded that the age level of workers has a significant effect on the labor productivity of reinforced concrete.

Testing the Assumption of the Regression Model. The regression model can be said that it fulfills the assumption of normality if the error or residual caused by the regression model is normally distributed. To test this assumption, the Kolmogorov-Smirnov method can be used, as viewed in table 9 as follows:

Table 9 - Test for Normality Assumptions

\begin{tabular}{|c|c|c|}
\hline Test Statistics & Score & Information \\
\hline Kolmogorov-Smirnov Z & 1,437 & \multirow{2}{*}{ Normal distribution } \\
\hline$p$-value & 0,253 & \\
\hline
\end{tabular}

Based on the Kolmogorov-Smirnov $Z$ test above, the $p$-value is 0.253 , where the value is greater than $\alpha=0.05$. From the test it was shown that errors or residuals had a normal distribution. So it can be concluded that the assumption of error normality has been fulfilled. 
Normal P-P Plot of Regression Standardized Residuat

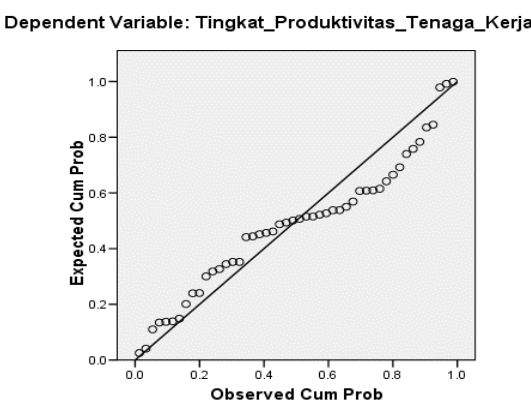

Figure 1 - Plot Graph of Labor Productivity Levels

If the unstandardized residual value or error value is expressed in a PP Plot graph, it can be viewed that the plot of the error forms a pattern that approaches to straight line as shown in Figure 1. The pattern in Figure 1 indicates that the error has a normal distribution because the plot of the pattern forms a pattern straight line. And if the error value is grouped in a histogram, then the errors will form a normal distribution curve pattern, that is, the error grouped in the middle with its peak point at an average of 0,000 as shown in figure 4.2 below:

Histogram

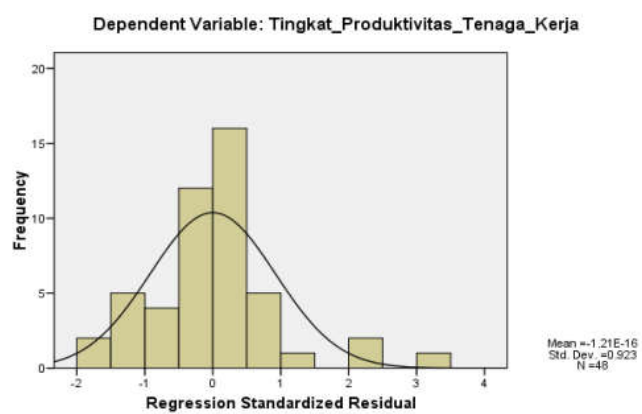

Figure 2 - Histogram Test for Normality Assumptions

To detect the presence or absence of multicollinearity can be viewed from the Variance Inflation Factor (VIF). If the VIF value is $>10$, it indicates multicollinearity. And if the opposite, VIF $<10$, there is no multicollinearity as seen in table 10 as follows:

Table 10 - Testing for assumption of multicollinearity

\begin{tabular}{|c|c|c|}
\hline Independent variables & VIF & Information \\
\hline Motivation to work (X1) & 4,513 & Non Multicollinearity \\
\hline Skills (X2) & 1,190 & Non Multicollinearity \\
\hline Discipline (X3) & 4,309 & Non Multicollinearity \\
\hline Education (X4) & 1,023 & Non Multicollinearity \\
\hline Experience (X5) & 1,429 & Non Multicollinearity \\
\hline Wage/salary (X6) & 1,192 & Non Multicollinearity \\
\hline Age (X7) & 1,465 & Non Multicollinearity \\
\hline
\end{tabular}

From the results of calculations in Table 10, each independent variable indicates the value of VIF, it is no more than 10 , so the assumption that multicollinearity has not occurred has been fulfilled. The objectives of this testing is to test whether the regression model has the same variance or not. A good regression model is a model that has the same variance (homocedasticity). Examination of this assumption can be conducted by using the Spearman rank correlation test, which is to examine the correlation between the predicted value and the error value. The test results with the Spearman's rank correlation method can be viewed as in table 11 as follows: 
Table 11 - Testing for assumption of homoscedasticity

\begin{tabular}{|c|c|c|}
\hline Test Statistics & Score & Information \\
\cline { 1 - 2 } Spearman's rank correlation & 0,000 & \multirow{2}{*}{ Homocedasticity } \\
\hline$p$ p-value & 1,000 & \\
\hline
\end{tabular}

Based on the table 11 above, Examination of this assumption can be obtained that coefficient of the spearman's rank correlation, it is about 0.000 with the p-value is about 1.000 , because the $p$-value is greater than $\alpha=0,05$. Based of this examination can be concluded that the assumption of homocedasticity has been fulfilled.

To test for autocorrelation, the Durbin-Watson test statistic is used, the results of the test can be view in table 12 as follows:

Table 12 - Test of Assumptions for Non-Autocorrelation

\begin{tabular}{|c|c|c|c|c|}
\hline Coefficient d & $\mathrm{dL}$ & $\mathrm{dU}$ & $4-\mathrm{d}$ & Information \\
\hline 1,391 & 1,224 & 1,882 & 2,118 & There is no autocorrelation \\
\hline
\end{tabular}

Source: SPSS Analysis Results.

Based on Table 12 above, the Durbin-Watson coefficient is 1.391. In the DurbinWatson Table it is known that $\mathrm{dL}+1,224$ and $\mathrm{dU}=1,882$. From the table above it is shown that $\mathrm{d}>\mathrm{dU}(1.391<1.80)$ and $4-\mathrm{d}>\mathrm{dU}(2.118>1.882)$. So it can be concluded that there is autocorrelation between errors and non-autocorrelation assumptions that have been fulfilled.

Before the equalization of the results of Researchers with the Indonesian National Standard 2002, the equalization of working time (working hours) and equalization of the composition of the work were first carried out.

Table 13 - Equalization of Working time and Composition of Work between Observation Results and Indonesian National Standard (SNI) 2002

\begin{tabular}{|c|l|c|c|c|}
\hline \multirow{2}{*}{ No } & \multicolumn{1}{|c|}{ Type of work } & Component & \multirow{2}{*}{$\begin{array}{c}\text { Composition of } \\
\text { Adjustment Coefficient }\end{array}$} \\
\cline { 3 - 4 } & \multicolumn{1}{|c|}{$\begin{array}{c}\text { Research Results of Reinforced } \\
\text { Concrete }\end{array}$} & 7 & $1 \mathrm{Tk}: 2 \mathrm{Pk}$ & 1,47 \\
\hline II & $\begin{array}{l}\text { Reinforced Concrete of Indonesian } \\
\text { National Standard }\end{array}$ & 5 & $1 \mathrm{Tk}: 11 / 2 \mathrm{Pk}$ & 1,20 \\
\hline
\end{tabular}

Data Source: Tjaturono (2002).

Based on table 13, the equalization coefficient of the results of research with SNI 2002 is as follows:

The equalization of working hours for labor productivity of reinforced concrete has an equalization value $=5 / 7=0.714$. From the results of the equalization of working hours and the composition of work between the results of research and Indonesian National Standard (SNI) 2002, the actual equivalence results can be used as a comparison between actual productivity based on the results of research in the field with the Indonesian National Standard (SNI 2002), where the equalization results can be calculated by multiplying the results equalizing the composition of working hours with the composition of work carried out with the magnitude of the actual productivity results of research in the field as follows:

$$
\text { Work of reinforced concrete }=5 \times 7 \times 5,575=3,982
$$

Result of equalization can be viewed as in table 14 as follow:

Table 14 - Result of equalization to the result of observation with Indonesian National Standard 2002

\begin{tabular}{|c|c|c|c|c|}
\hline No & Type of Research & Result of Research & Result of Equalization & SNI 2002 \\
\hline 1 & Pek. Reinforced Concrete & $5,575 \mathrm{~m}^{3} /$ day & $3,982 \mathrm{~m}^{3} /$ day & $2,857 \mathrm{~m}^{3} / \mathrm{day}$ \\
\hline
\end{tabular}


From table 14 it is known that the labor productivity of actual reinforced concrete is based on the results of the research and after equalization of $3.982 \mathrm{~m} 3$ / day, while the 2002 $\mathrm{SNI}$ is $2.857 \mathrm{~m} 3$ / day, this shows that the actual results of labor productivity in the study are higher (greater) $28,25 \%$ of the labor productivity results contained in Indonesian National Standard (SNI) 2002.

The One Sample $t$ Test is used to test whether the labor productivity of real reinforced concrete is different (there are differences) with the labor productivity of reinforced concrete in the 2002 Indonesian National Standard (SNI). The test uses the SPSS 15 software tool and the results obtained as shown in Table 15 are as follows:

Table 15 - The result of One Sample t Test

One-Sample Test

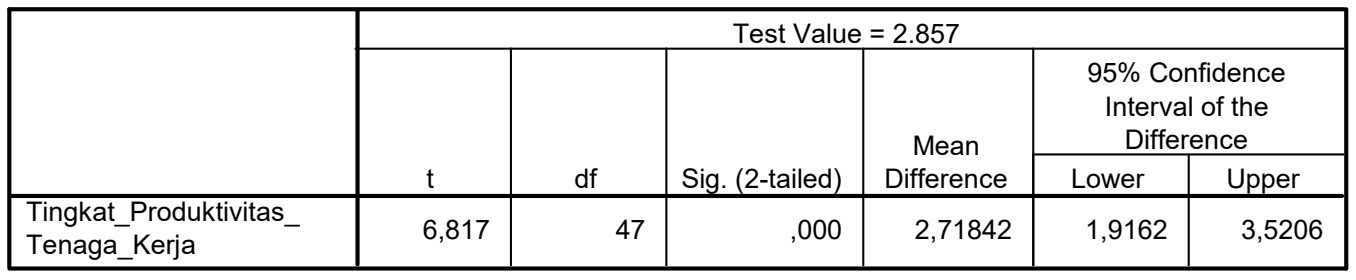

By using the help of SPSS software, the tcount test statistic obtained is 6.817 with a pvalue of 0.000 . The value of t-test statistic is greater than $t$ table $(6.817>1.683)$ and even $p$ value is smaller than $\alpha=0.05$. This test shows that $\mathrm{HO}$ is rejected. So that it can be concluded that the labor productivity of real reinforced concrete of research results are different from the labor productivity of reinforced concrete in the Indonesian National Standard (SNI) 2002.

\section{DISCUSSION OF RESULTS}

From the results of research in the field by using descriptive analysis, the labor productivity of reinforced concrete in the Office Buildings of Bontang Kuala District in Bontang City was $5.575 \mathrm{~m} 3$ / day and productivity in Indonesian National Standard (SNI) in 2002 was $2.857 \mathrm{~m} 3$ / day, while labor productivity of actual reinforced concrete was based on research $3.982 \mathrm{~m} 3$ / day. It means that the labor productivity of research results in the field is 28.25\% higher than Indonesian National Standard (SNI) 2002. With this difference, where the productivity value of the research results is greater, the labor productivity of coefficient value of Indonesian National Standard (SNI) 2002 is still suitable to be used in planning calculations in Bontang kuala city, East Kalimantan province.

From the $F$ test, it is found that the Motivation to work (X1), Skills (X2), Discipline (X3), Education (X4), Experience (X5), Wages / Salaries (X6) and Age (X7) factors influence simultaneously on labor productivity reinforced concrete is 10,470 . But partially the factors that significantly influence the labor productivity of reinforced concrete are experience factors (X5) with an $\beta$ coefficient of 1.753 and age (X7) with an $\beta$ coefficient of 1.484 , while the most dominant factor affecting the labor productivity of reinforced concrete is the factor that has the highest standardized $\beta$ coefficient value, namely experience (X5) with an $\beta$ coefficient of 1,753 .

Experience is a major factor for labor in producing their products. The higher the experience of the workforce, the greater the product will be when compared to the workforce having less experience in the same timeframe (eg: $\mathrm{m} 3$ / day). Therefore for users of labor, factors the experience of the workforce should be considered to get high labor productivity. Based on the results of one sample $t$ test, it can be concluded that the real of labor productivity of reinforced concrete of the research results is different from the labor productivity of reinforced concrete in the Indonesian National Standard (SNI) 2002, where productivity is higher (greater) $28.25 \%$ than productivity SNI 2002. This research was only carried out with the composition of 1 artisan 2 workers. Changes in the composition of work 
will also change productivity (Tjaturono, 2002). Therefore, to find out the maximum productivity, further research is needed with other work compositions.

\section{CONCLUSION}

The magnitude of the average of labor productivity of reinforced concrete produced by the Office Buildings of Bontang Kuala District in Bontang City is $5.575 \mathrm{~m} 3$ / day with the composition of 1 handyman: 2 workers.

The results of equalization of labor productivity of reinforced concrete is $3.982 \mathrm{~m} 3 /$ day, while 2002 labor productivity of Indonesian National Standard SNI is $2.857 \mathrm{~m} 3$ / day so that the difference between real labor productivity and labor productivity of Indonesian National Standard (SNI) is $28.25 \%$.

From the $F$ test, it is found that Motivation (X1), Skills (X2), Discipline (X3), Education (X4), Experience (X5), Wages / Salaries (X6) and Age (X7) factors have an effect simultaneously on labor productivity of reinforced concrete with a value of Fcount $=10.470 \mathrm{>}$ Ftable $=2.210$. But the results of the partial t test of the factors that significantly influence the labor productivity of reinforced concrete are:

- Experience factor (X5) with a tcount value $=4.255>\mathrm{t}$ table $=1.683$.

- Age factor (X7) with a value of the coefficient of tcount $=3.612>t$ table $=1.683$.

From the results of the regression analysis, it is concluded that the most dominant variable on the labor productivity of reinforced concrete is experience factor (X5) with an $\beta$ coefficient of 1.753. Experience factor is the main factor in producing a product.

\section{REFERENCES}

1. Azwar, 1999, Metode Penelitian, Sigma Alpha Yokyakarta.

2. Dipohusodo, I. 1995, Manajemen Proyek dan Kontruksi. Edisi ketujuh, Penerbit Kanisius Yogyakarta.

3. Kaming, P.F., E. Setyanto, \& Henry, 1997. Analisis Biaya Kontruksi Bangunan Gedung. VASTHU - Jurnal Fakultas Teknik Atmajaya, Yogyakarta, no 3/th. V, Agustus, 13-20. Yogyakarta.

4. Kaming, P.F., E. Setyanto, 2000, Study tentang Produktivitas Tenaga Kerja Konstruksi di Yogyakarta dan sekitarnya, Proceeding Of Conference Of Contruction Project Management Critical Isue And Challenge Into The Next Millenium 5667. Yogyakarta.

5. McGrath, M. E. (2004). Next generation product development: how to increase productivity, cut costs, and reduce cycle times(Vol. 1). New York: McGraw-Hill.

6. Noe, R., Hollenbeck, J., Gerhart, B., \& Wright, P. (2006). Human Resources Management: Gaining a Competitive Advantage, Tenth Global Edition. McGraw-Hill Education.

7. Omachonu, V. K. (2012). Total quality and productivity management in health care organizations. Georgia: Industrial Engineering and Management Press, 1991.

8. Smith, N.J, 2002, Engenering Project Manajement. Second Ed. Blackwell Science Ltd.

9. Soeharto, I. 2001. Manajemen Proyek Dari Konseptual Sampai Operasional. Erlangga. Jakarta

10. Sugiono, 2006, Statistika untuk Penelitian, CV ALFABETA Bandung.

11. Tjaturono, 2002, Analisis Komposisi Kelompok Kerja Terhadap Produktivitas Tenaga Kerja. Di Jawa Timur. Prosiding seminar Nasional ITS September 2002. Surabaya. 